\title{
The Vjosa River corridor: a model of natural hydro- morphodynamics and a hotspot of highly threatened ecosystems of European significance
}

\author{
Fritz Schiemer • Sajmir Beqiraj • Anton Drescher • Wolfram Graf • \\ Gregory Egger • Franz Essl - Thomas Frank • Christoph Hauer • \\ Severin Hohensinner • Aleko Miho • Paul Meulenbroek • Wolfgang Paill • \\ Ulrich Schwarz $\cdot$ Simon Vitecek
}

Received: 22 October 2019/Accepted: 6 March 2020/Published online: 20 March 2020

(C) The Author(s) 2020

\begin{abstract}
Context Large near-natural rivers have become rare in Europe, a fact reflected in the high conservation status of many riverine ecosystems. While the Balkan still harbors several intact river corridors, most of these are under pressure from planned hydropower constructions. Unfortunately, there is little information available on the hydromorphodynamics and biota of Balkan rivers under threat.
\end{abstract}

Electronic supplementary material The online version of this article (https://doi.org/10.1007/s10980-020-00993-y) contains supplementary material, which is available to authorized users.

F. Schiemer $(\bowtie)$

Department of Limnology and Bio-Oceanography, University of Vienna, Althanstr.14, Vienna 1090, Austria e-mail: friedrich.schiemer@univie.ac.at

\section{S. Beqiraj · A. Miho}

Department of Biology, University of Tirana, Tirana, Albania

e-mail: sajmir.beqiraj@fshn.edu.al

A. Miho

e-mail: aleko.miho@fshn.edu.al

\section{A. Drescher}

Instiutute of Biology, Division of Plant Sciences, University of Graz, Holteigasse 6, Graz 8010, Austria e-mail: anton.drescher@uni-graz.at
Objectives We present a synthesis of research on the Vjosa in Southern Albania. Here, longitudinal continuity in water flow, undisturbed sediment transport and intact fluvial dynamics are still maintained, but threatened by two large dams planned in its downstream section. We intend to provide a first multidisciplinary inventory of this river system as an example of the knowledge base required for sound water management decisions in the Balkans.

Methods Based on field work of a multidisciplinary consortium of scientists from Albania and other countries conducted from 2017 onwards, we summarize the most important findings on geomorphology of

W. Graf · S. Hohensinner · P. Meulenbroek Institute of Hydrobiology and Aquatic Ecosystem Management, University of Natural Resources and Life Sciences, Gregor-Mendel-Straße 33, Vienna 1180, Austria e-mail: wolfram.graf@boku.ac.at

S. Hohensinner

e-mail: severin.hohensinner@boku.ac.at

P. Meulenbroek

e-mail: paul.meulenbroek@boku.ac.at

G. Egger

Institute of Geography and Geoecology, Department of Wetland Ecology, Karlsruhe Institute of Technology, Josefsstraße 1, Rastatt 76437, Germany

e-mail: gregory.egger@kit.edu 
the riverine landscape, habitat turnover rates, vegetation ecology and selected animal taxa.

Results We found evidence that significant areas $(86 \%)$ of the river corridor are covered by habitats listed in Annex 1 of the European Union Habitats Directive. These are associated with a high number of threatened biota.

Conclusions Our findings underscore the value of the Vjosa as one of the few remaining reference sites for dynamic floodplains in Europe and as a natural laboratory for interdisciplinary research. We emphasize that such multidisciplinary studies are a prerequisite for informed evaluation of potential impacts caused by hydropower plants.

Keywords Balkans rivers - EU-regulations - Habitat turnover - Hydropower - Stenotopic floodplain biota Vegetation succession

\section{The Balkans-the blue heart of Europe}

Stretching from Slovenia to northern Greece, the Balkans (Balkan Peninsula, see Fig. 1) are home to most of the remaining intact river systems in Europe with the exception of the arctic and boreal ecoregions. The majority of Balkan rivers are in an excellent hydromorphological state, a situation that is highly exceptional in Europe. This holds especially true for Montenegro and Albania (Fig. 1). The region in general, and its rivers in particular, are recognized as biodiversity hotspots with many endemic species (Griffith et al. 2004). However, recently, Balkan rivers

F. Essl

Department of Botany and Biodiversity Research, University of Vienna, Rennweg 14, Vienna 1030, Austria e-mail: franz.ess1@univie.ac.at

T. Frank

Institute of Zoology, University of Natural Resources and Life Sciences, Gregor-Mendel-Straße 33, Vienna 1180,

Austria

e-mail: thomas.frank@boku.ac.at

C. Hauer

Christian Doppler Laboratory for Sediment Research and Management, University of Natural Resources and Life Sciences, Muthgasse 107, Vienna 1190, Austria e-mail: christoph.hauer@boku.ac.at have come under strong pressure from around 3000 planned hydropower projects, of which more than 1000 are located in protected areas such as national parks, nature reserves and Natura 2000 sites (see "Eco-Masterplan for Balkan rivers" 2018). In many cases, the conservation value of rivers impacted by the proposed hydropower projects is insufficiently known, and environmental impact assessments are often inadequate.

Here, we provide a multidisciplinary synthesis of the conservation value of the Vjosa in southern Albania which is one of the last large European rivers in excellent hydromorphological condition throughout its entire course. The river has recently come under threat from two commissioned hydropower dams at its lower section (see Fig. 2a). While it is evident that the construction of these hydropower plants would have a severe impact on the conservation value of the Vjosa, the decision for constructing these dams has been made without a comprehensive assessment of possible environmental and socio-economic effects and without considering possible alternatives.

Thus, a joint action of research teams from Albania, Austria and Germany was instigated in 2017 to survey the river sections that would be directly affected. While the detailed results have been made available in a recent monograph (Schiemer et al. 2018a, b), here we provide a synthesis of the results and discuss them in a broader context. In particular, we address the geomorphological dynamics of the river and its floodplains, examine habitat diversity and habitat turnover rates, present a model on vegetation succession and discuss characteristic aquatic and terrestrial

W. Paill

Universalmuseum Joanneum, Weinzöttlstraße 16, Graz 8045, Austria

e-mail: wolfgang.paill@museum-joanneum.at

U. Schwarz

Fluvius: Floodplain Ecology and River Basin Management, Hetzgasse 22, Vienna 1030, Austria e-mail: office@fluvius.com

S. Vitecek

WasserCluster Lunz, Dr.-Carl-Kupelwieser Promenade 5, Lunz 3293, Austria

e-mail: simon.vitecek@wcl.ac.at 


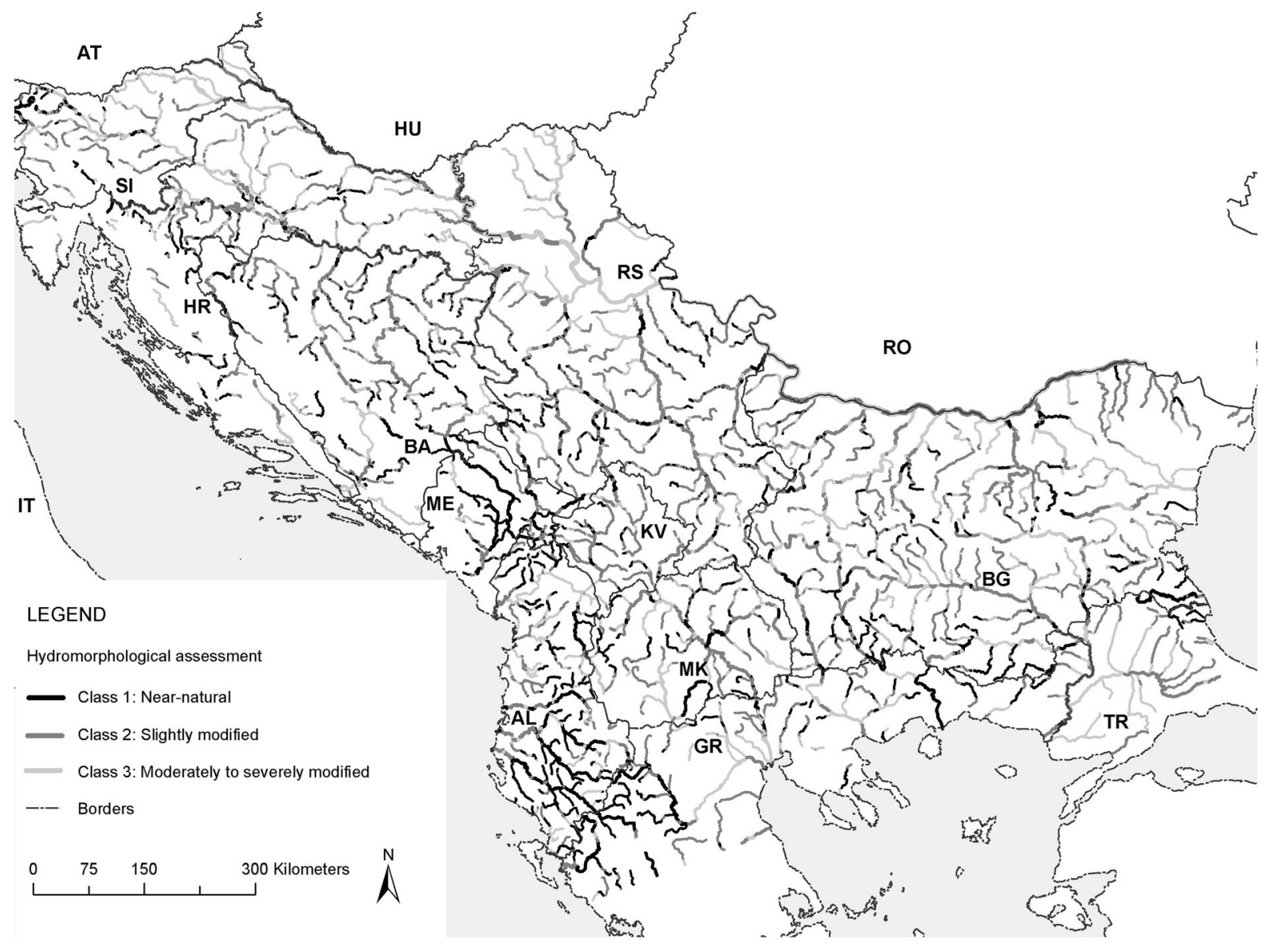

Fig. 1 Hydromorphological status of rivers with a catchment size over $500 \mathrm{~km}^{2}$ in the Balkan Peninsula (acc. to "Ecomasterplan Balkan 2018). Class 1 near-natural, class 2 slightly modified, class 3 moderately to severely modified. Balkan countries SL (Slovenia), HR (Croatia), RS (Serbia), BA (Bosnia-Herzegovina), ME (Montenegro), AL (Albania), KV

fauna. Our results support the urgency for conservation.

\section{Study site and methods}

A detailed description of the Vjosa and its accompanying landscapes is available in Schiemer et al. (2018a, b). In brief, the river extends over $272 \mathrm{~km}$ from its sources in the Pindos mountains (at 1343 m.a.s.1.) east of Ioannina in Greece through the south of Albania to the Adriatic Sea. Its catchment covers $6704 \mathrm{~km}^{2}$ of which $4365 \mathrm{~km}^{2}$ are on Albanian territory. The first $80 \mathrm{~km}$ are situated in Greece, where
(Kosovo), GR (Greece), BG (Bulgaria), TR (Turkey). Neighboring countries AT (Austria), HU (Hungary), RO (Romania), IT (Italy). Within the Balkan $25 \%$ of the rivers are hydromorphologically in "near to natural" conditions (compared to $10 \%$ in Germany)

the river is named Aoos. The overall geomorphology of the Vjosa basin is characterized by a NW-SE orientation of the folded structures and tectonic planes (Fig. 2a). Along its course a variety of channel types occurs, with gorges in the upper parts, braiding and anabranching sections in the middle and lower courses and meandering stretches close to the river mouth. The climate of the lower catchment is Mediterranean, grading further upstream into sub-Mediterranean, temperate and finally-at its source in the mountains-alpine climates. The hydrological regime is classified as pluvio-nival. On average, the flow of the river exhibits a distinct seasonal pattern with high discharge from December to April, intermediate flows 

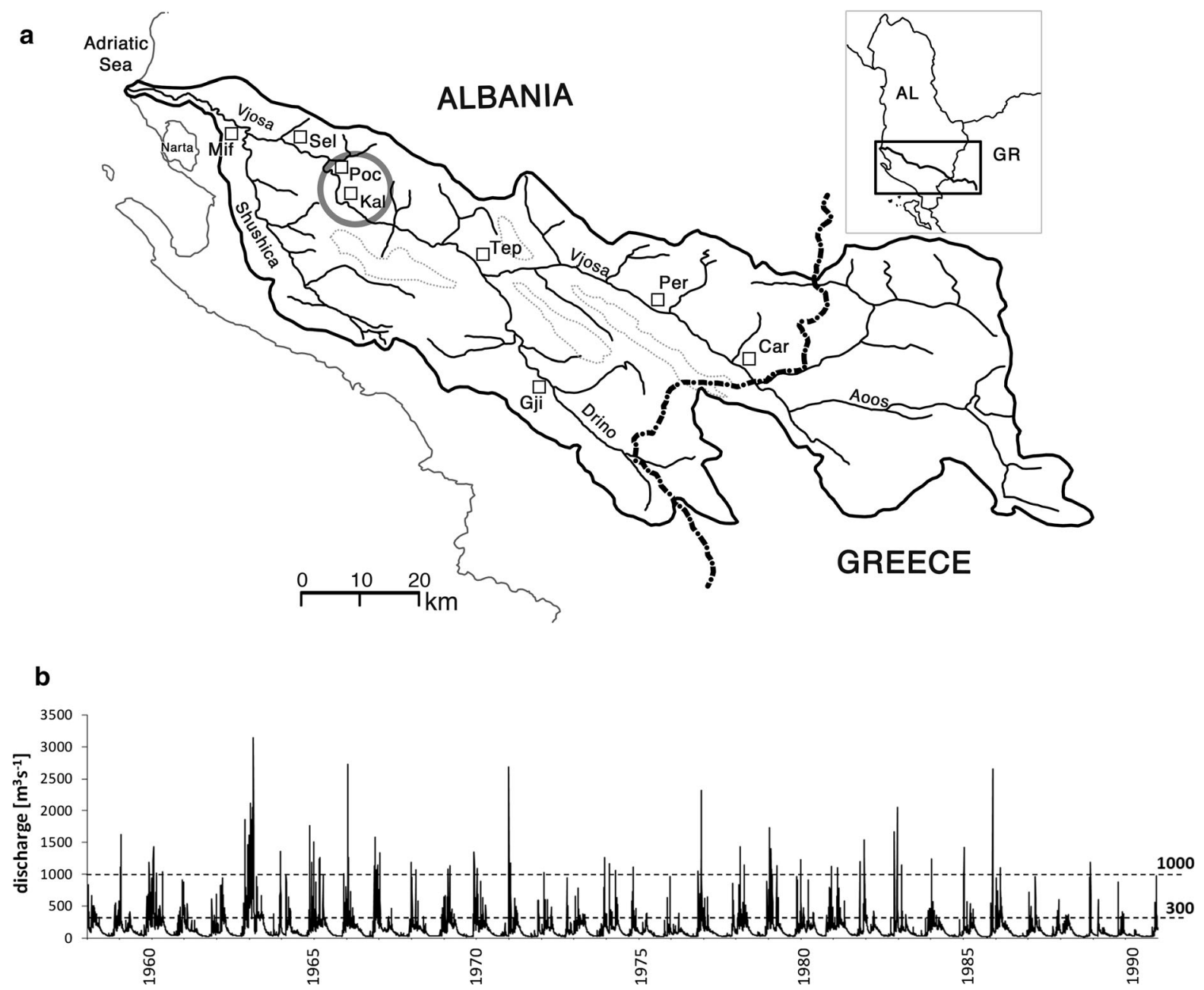

Fig. 2 a The Vjosa catchment. Shown are major mountain ranges in Albania (dotted line) and the major cities: Mif (Mifoli), Sel (Selenica), Poc (Poçemi), Kal (Kalivaçi), Tep (Tepelena), Per (Permet), Car (Çarshova), Gji (Gjirokastro). The study area upstream of Poçemi, where the two hydropower plants are planned, is indicated by a circle. b Daily discharges of

in May and October and low flow from June to September. Daily discharge is highly unpredictable (Fig. 2b). The annual mean flow at Poçemi is $141.5 \mathrm{~m}^{3} \mathrm{~s}^{-1}$, the recorded maximum was 3140 $\mathrm{m}^{3} \mathrm{~s}^{-1}$ (1963).

Our assessment focused on the lower section of the Vjosa at Poçemi and Kalivaçi, which represents a barbraided and island braided river type with extensive floodplains (Fig. 3a). We identified the hydro-morphological and habitat dynamics of the river-floodplain system at a range of spatio-temporal scales. The landscape development over the past 50 years was the Vjosa for the time period 1958-1990. Hydrometer at Dorez, (upstream of Poçemi). After 1990 the gauging station was closed. The broken horizontal lines at $300 \mathrm{~m}^{3} \mathrm{~s}^{-1}$ and 1,000 $\mathrm{m}^{3} \mathrm{~s}^{-1}$ indicate the initiation of bed load transport in the channel and the discharge overtopping into the floodplains, respectively

reconstructed from a series of satellite images from 1968 onwards. In a detailed review of about 30 available images, those from 1968, 2006, 2012 and 2016 (Google Earth 2018) were analyzed with regard to the long-term translocations of the active channel within the floodplain. Satellite images were selected according to their temporal distribution, water level and spatial resolution for interpretation.

To gain a better understanding of the driving forces of the landscape dynamics, terrestrial surveys along three representative transects of the river-floodplain morphology were conducted using a Leica TC805 
a

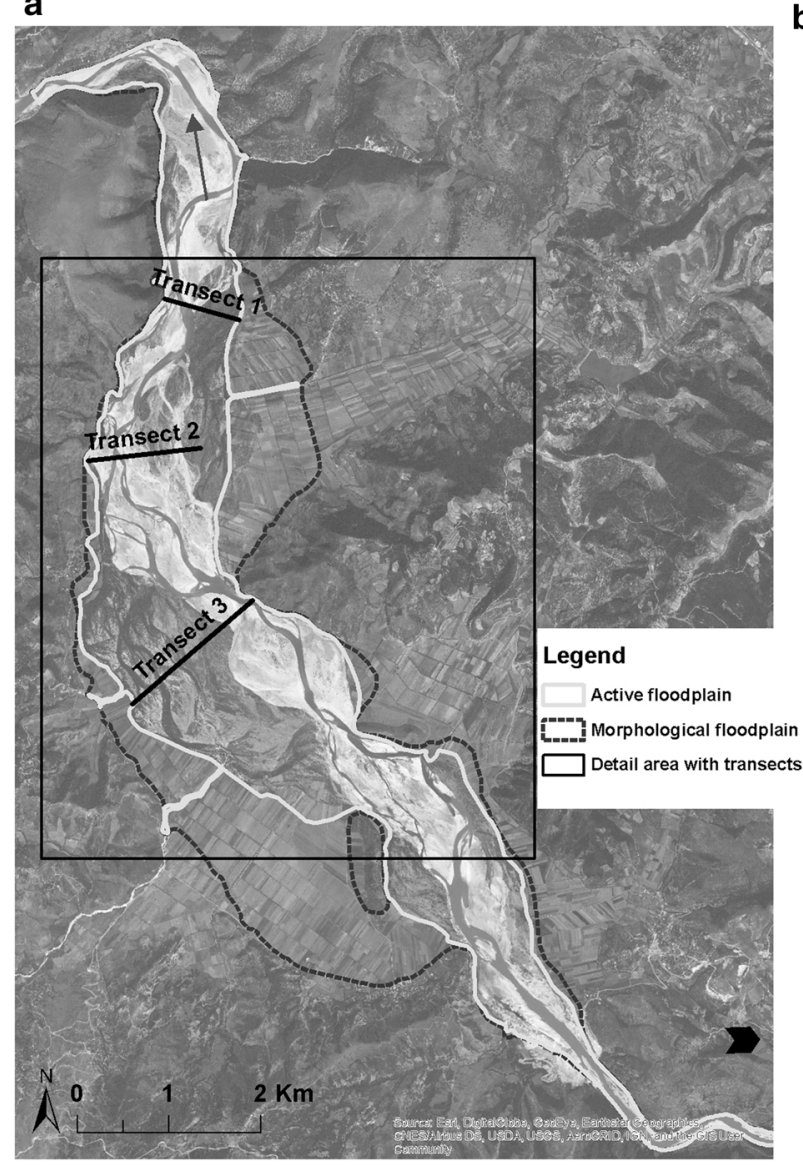

Fig. 3 a Satellite overviews (2012) of the river-floodplain section upstream of Poçemi. The "active channel" (AC) is represented by the bright band. Delineated are the outer borders of the "active floodplain" (AF) and the "morphological floodplain" (MF), defined by the breadth of the valley floor. The AF is regularly (at a high flow of approximately 5-10 years flood recurrence) flooded. The MF, the area outside the AF, is

total station in April 2017 and July 2018 (Figs. 3a, 4). Integrating this analysis of relief changes of the riverine landscape with available flow data allows for an approximation of the extensive sediment transport and morpho-structural dynamics. Morphological classification (following Nanson and Knighton 1996) of the floodplain at Poçemi was achieved with a onedimensional hydrodynamic-numerical model: bankfull discharge capacity $\left(\mathrm{m}^{3} \mathrm{~s}^{-1}\right)$, bottom shear stress $\left(\mathrm{Nm}^{-2}\right)$ and unit stream power $\left(\mathrm{Wm}^{-2}\right)$ were analyzed for characteristic discharges (mean flow - maximum recorded floods). For measurements of sediment transport processes see Hauer et al. (2019). b

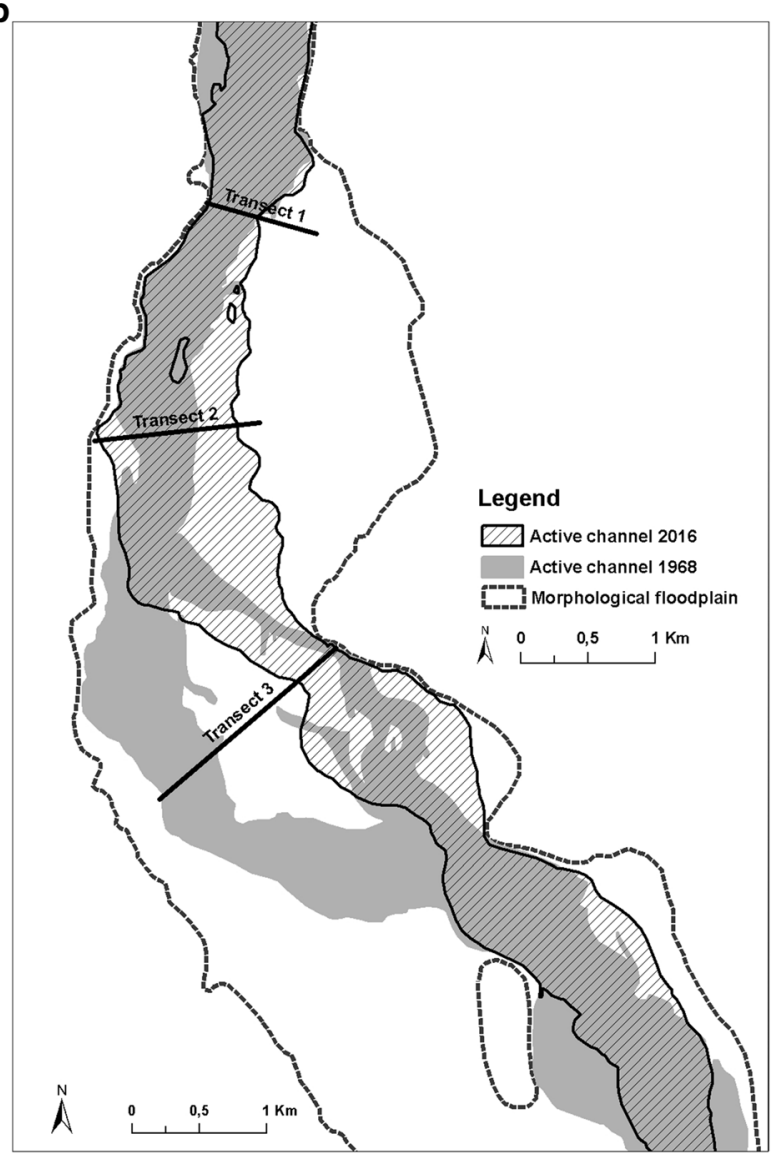

only flooded sporadically at very high floods (high flow $>100$ years). This area is largely used as arable land. The solid rectangular box delineates the area where three transects were established to study habitat, morphological and biotic composition and turnover during the study period. b Long-term translocation of the active channel between 1968 and 2016. The outer borders of the morphological floodplains are marked

For an assessment of habitat distribution and turnover at smaller scale satellite images were analyzed from 2006, 2012 to 2016 (Fig. 5, Table 2). Vegetation surveys were carried out in 69 plots (relevés) along the three transects in April and September 2017 and compared to the analysis of satellite images. Plot size varied between 25 and 100 $\mathrm{m}^{2}$, depending on vegetation type. Obtained data were classified using TWINSPAN (Hill 1979) to describe succession patterns of floodplain vegetation (Fig. 6b). For details see Drescher 2018.

Habitats covered by the EU Habitats Directive (Annex 1, European Commission 2013) of the river corridor of the Poçemi-Kalivaçi section were 

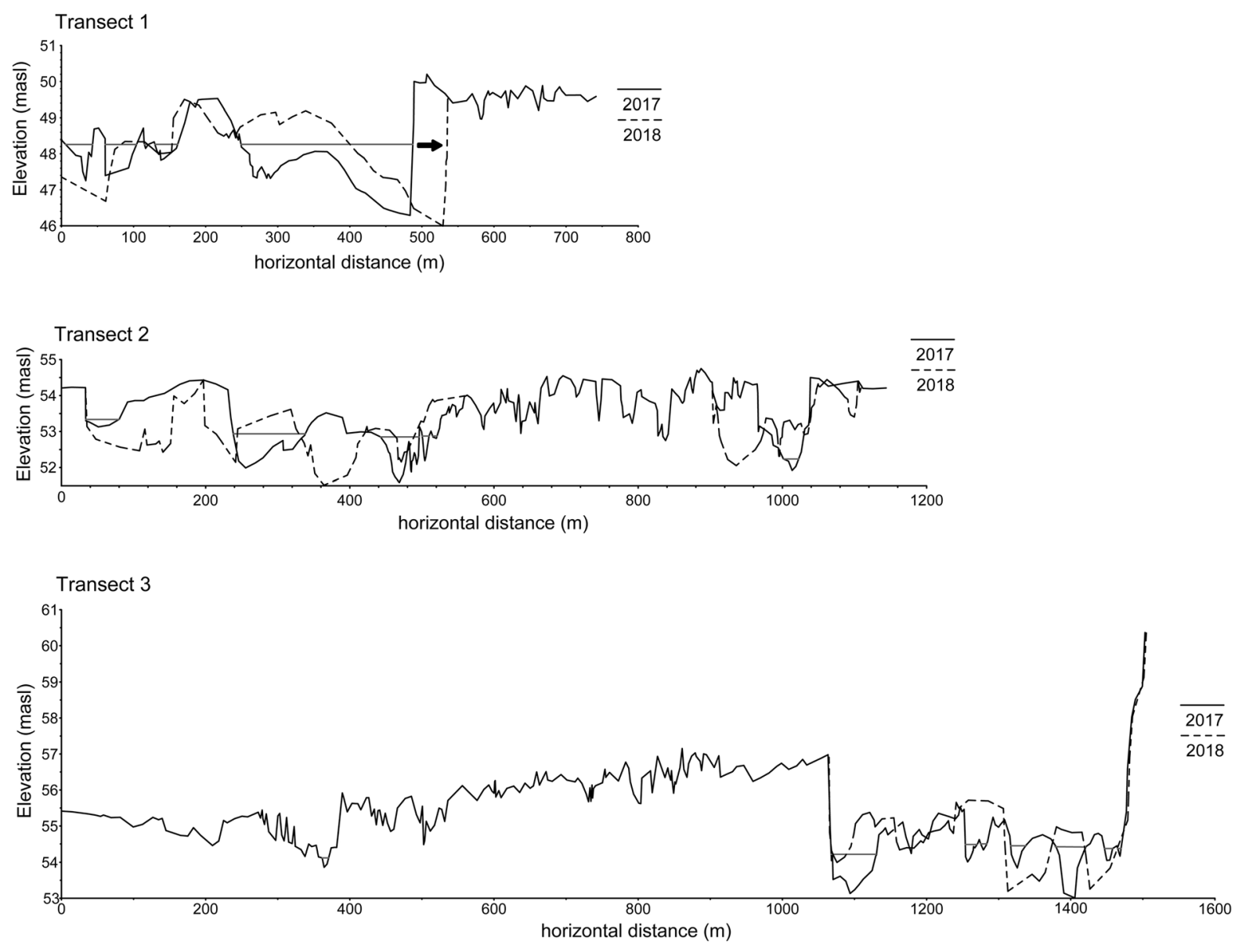

Fig. 4 Change in the river-floodplain relief from 2017 to 2018 along three transects shown in Fig. 3a. Distances along the transect from left (as anchor point) to right. The horizontal line marks the water level at the flow during sampling in 2017 (approx. $50 \mathrm{~m}^{3} \mathrm{~s}^{-1}$ )

mapped in May 2019 in combination with aerial images (Esri) (Egger et al. 2019).

The study of the diversity of benthic invertebrate fauna was designed as a faunistic survey, conducted as a stratified sampling program along three transects. Larval samples were taken with a $250 \mu \mathrm{m}$ $25 \times 25 \mathrm{~cm}$ hand net, observing standardized sampling routines. Additionally, adult aquatic insects were collected with sweep nets and light trapping.

Juvenile and adult fish were caught by point abundance electrofishing (EF) (Copp and Peňáz 1988) at wadable sites in April 2017. For EF, a backpack-generator (ELT60-IIH from H. Grassl) was used. Additional gill nets were placed at selected sites with a mesh size of $20 \mathrm{~mm}$ and $50 \mathrm{~mm}$. For more detailed information see Meulenbroek et al. (2018).

Surveys on the riparian invertebrate fauna were conducted from 24.04.2017 to 28.04.2017. In particular, 150 pitfall traps were applied at 30 sites arranged along Transect 2 (Fig. 3a) with 20 additional sampling sites studied by time-standardized handcollections. To record amphibian and reptile species, transect campaigns along the Vjosa River were performed in 2016 and 2017.

\section{Results}

Landscape dynamics

There is a clear distinction between the active channel (bright band) and the elevated floodplain (Fig. 3a). The width of the active channel (AC) varies between 400 and $1000 \mathrm{~m}$. Larger islands and gravel bars within the AC are strongly structured by erosion channels and show the cumulative effects of changing water levels 


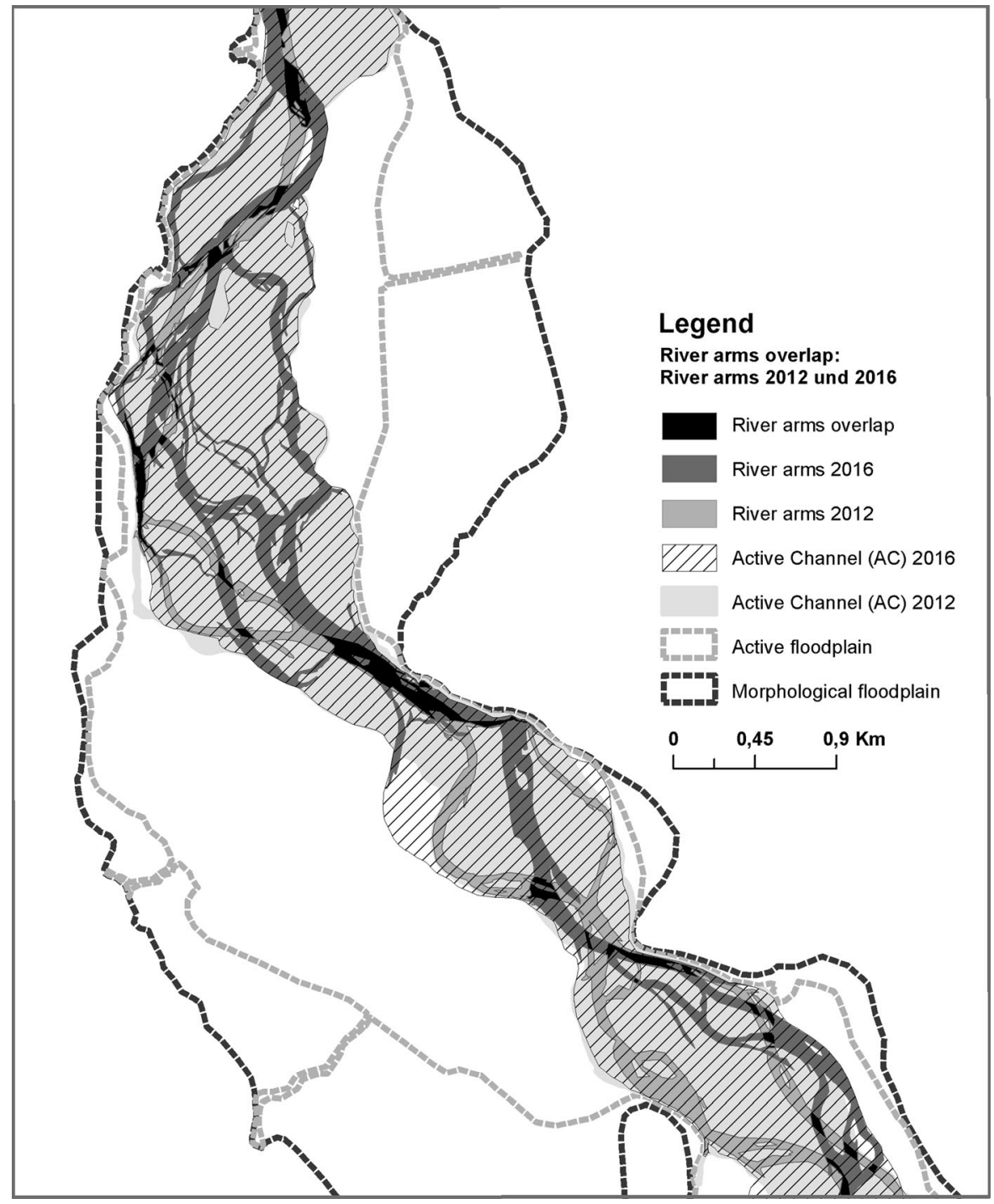

Fig. 5 Mid-term structural changes in the river - floodplain area of the Poçemi floodplain between 2012 and 2016. The graph shows the almost complete change in position of the

and flow pulses. Within the AC large bars are deposited and more perennial islands are formed as is characteristic for island braided river sections. The river segments under consideration are partially constrained by bedrock structures leading to a high variability in the lateral extent of the riverine landscape. Gorges constitute bottlenecks in sediment transport resulting not only in lateral but also in longitudinal sorting processes. Besides the high gravel load, a large amount of finer sediments is transported by the river - a significant feature that creates large silt anabranching river system. The dark area shows the overlap in the position of the river between 2012 and 2016

deposit areas but also causes high compaction and reduced porosity of the river bed. The floodplain is characterized by extraordinarily high dynamics and relocation of the AC, partially due to channel avulsion (Fig. 3b). Its average relocation rate for the period between 1968-2016 was in the order of $1-1.4 \%$ per year of the AC area, which means that the riverfloodplain system is completely restructured within less than 100 years.

The impact of the flow dynamics is apparent from the two series of cross-sectional measurements over 


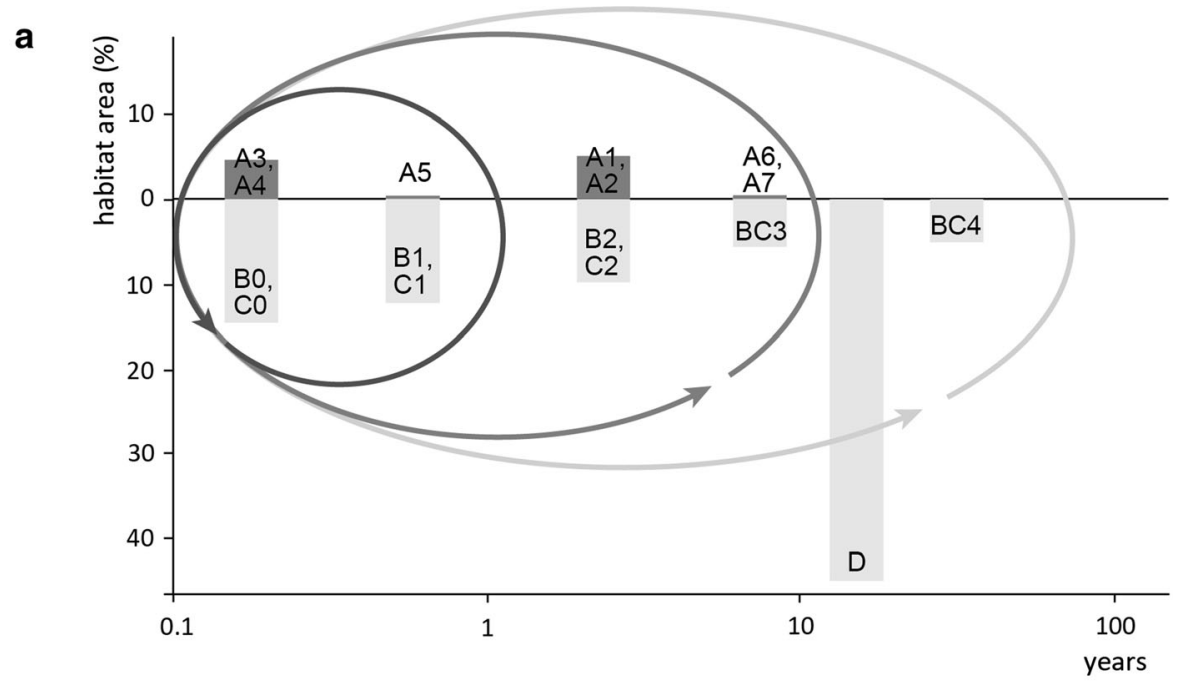

b

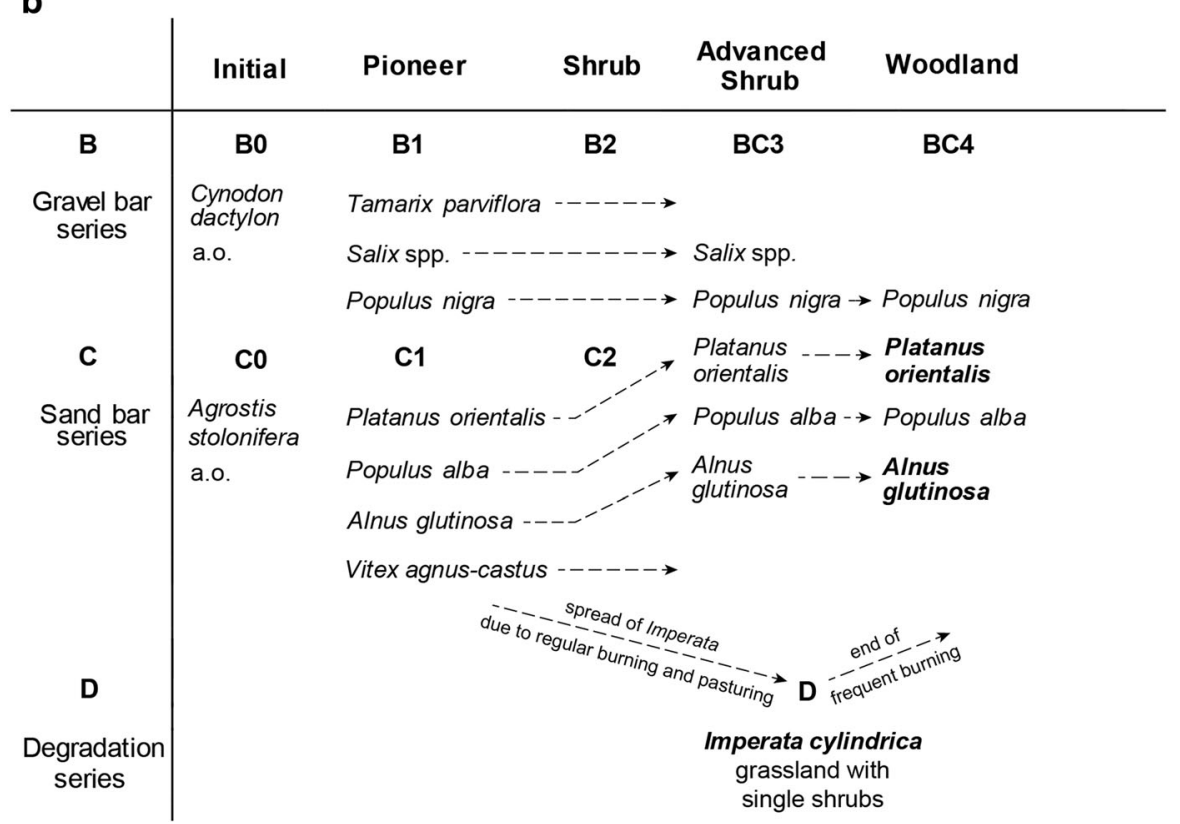

Fig. 6 a A general scheme of habitat composition and habitat turnover cycles (encircled). The percentage fraction of the various habitat types (aquatic: dark grey, upwards directed; terrestrial: bright grey, downwards directed columns) refer to the study area at Poçemi delineated in Fig. 3a during the period 2012-2016. The columns are arranged along the $\mathrm{x}$-axis with respect to their theoretical turnover rate. b Vegetation succession model: The heading denominates the progressive

the river-floodplain system in April 2017 and 2018. In between the two series a major flood event occurred in December 2017 (estimated discharge: $2000 \mathrm{~m}^{3} \mathrm{~s}^{-1}$, HQ5: 5 years flood recurrence time). The effects can be seen in both in the vertical as well as the lateral succession from the initial stages $\mathrm{B} 0$ and $\mathrm{C} 0$ to woodland (BC4). The dashed lines with arrows indicate a continued development. The succession is frequently interrupted and reset by flood events, depending on the distance from the main channel and elevation. The B- and C-series represent the difference in the succession series starting on coarse and fine grained sediment respectively. Dominant species are printed in bold. For a detailed discussion see text

changes of the river bathymetry and major side erosion in curved sections (see arrows in Fig. 4). Vertical aggregation and scouring occur in all parts of the main AC. The scarp at the border of the AC and the elevated floodplain is on average $2-3 \mathrm{~m}$ high, measured from 
the mean water level of the main river arm. The analysis of the discharge capacity of the AC indicates an overtopping of flow into the overbank areas at around $1000 \mathrm{~m}^{3} \mathrm{~s}^{-1}$ (Fig. 1b), which represents the height of an approximately annual flood event in the investigated river sections. The modelling approach enabled a quantification of driving morpho-dynamic parameters like bottom shear stress or stream power $\left(22.8 \mathrm{~W} \mathrm{~m}^{-2}-39.8 \mathrm{~W} \mathrm{~m}^{-2}\right)$ for $1000 \mathrm{~m}^{3} \mathrm{~s}^{-1}$ discharge. These numbers are at the lower boundary of gravel-dominated laterally active rivers (Nanson and Knighton 1996), such rivers being transitional between meandering and braided types (Deslodges and Church 1989). In the study site, extended stretches can be classified as island-braided with tendencies to anabranching. Channel sinuosity as well as the ratio of island length/channel width supported the classification of a laterally active gravel-bed river.

Based on direct sediment transport measurements in 2018, the initiation of bed load transport starts at $300-350 \mathrm{~m}^{3} \mathrm{~s}^{-1}$. Flows at or above these critical values occurred on average at $29 \pm 21$ days per year from 1958-1990 (Fig. 1b). Total load of transported sediments based on flow data for 2018, and on direct sediment transport monitoring techniques both of bed load and suspended sediments, yielded values of 5 Mil. tons $\mathrm{a}^{-1}$ for the Poçemi section, which constitutes a significant contribution to delta development and coastal protection (Hauer et al. 2019). The portion of suspended sediment is high: an interesting finding of the transect measurements (Fig. 4) is that the water levels of the main arm, the disconnected arms and erosion pools differ by up to one meter. This confirms that the lateral groundwater exchange is low, due to the high clogging of the riverine sediments.

Dynamic rivers create a wide range of habitat types and transition zones which change continuously at different spatio-temporal scales (see Table 1). Within the $\mathrm{AC}$, aquatic habitats range from fast current to stagnant conditions. Their ecological characteristicsat a microhabitat scale- - vary continuously with water table height. Even small water level fluctuations and "flow pulses" lead to continuous changes in the flowage line and habitat conditions, especially for the aquatic biota and the riparian fauna.

Terrestrial habitat types on elevated bars within the active channel and the elevated floodplains exhibit an even higher complexity. The main factors for differentiation are: (a) sediment sorting processes and sediment composition (grain size diameter) as a main factor for water capacity of the sediments and thus the germination of plants, (b) distance from the main river branches, (c) elevation above mean water table, (d) frequency and dimension of flow pulses resulting in different time spans for vegetation development, (e) the groundwater table, (f) timing and mode of seed dispersal, and ( $\mathrm{g}$ ) human impacts by logging, burning, or grazing. Within the active channel we can identify successions on gravel (B series) and on sand/ silt deposits ( $\mathrm{C}$ series) with higher water retention. On higher islands within the $\mathrm{AC}$ and in the elevated floodplain areas, the continuous dynamics of sedimentation and erosion processes lead generally to vertically structured depositions with alternating layers of coarser and finer sediments. As a consequence of several years of sedimentation a clear floristic distinction between a gravel (B-) and a fine sediment (C-) series is no longer possible (therefore $\mathrm{BC} 3$ and $\mathrm{BC} 4$ in Table 1, see Fig. 6b).

For the analysis of the quantitative composition of habitat elements and their spatio-temporal dynamics (Table 2), some of the habitat types were combined because they were either continuously interchanging with water level fluctuations (e.g. the riverine habitats A1-A4) or were not clearly discernable in the satellite images. The river with its downstream connected or disconnected side-arms (A1-A4) represents approximately $15-20 \%$ of the $\mathrm{AC}$ at low and mean water levels. The areal extent of erosion pools (type A5) is very low, yet they are very significant as habitat and refuge for many riverine landscape species. The unvegetated gravel and sand bars (B0 and $\mathrm{C} 0$ ) cover the largest area, about $50 \%$ of the AC. Small patches of softwood floodplain forests (BC4) can be found on larger accreted islands. Within the elevated floodplain such softwood floodplain forest patches are also rare and cover only small areas. The same holds true for wetlands (A6 and A7). At the elevated floodplains where grassland is dominant (D), turnover is expectedly lower and the observed structural changes are mainly due to human activities by grazing and burning.

The habitat turnover rates are particularly high within the AC (see Table 2, Fig. 5). The position of the multichannel river and all the major habitat elements, including smaller islands pioneer vegetation and shrubs, changes in the order of $10-20 \%$ per year at the habitat scale. Isolated erosion pools within the 
Table 1 Habitat types in the river floodplain of the Vjosa river, at low to mean flow, maintained by periodic flood conditions

Aquatic habitat types

A1: Main branches of the river, fast current in the thalweg

A2: Inshore zone of the main branch and shallow side branches, low current

A3: Downstream connected side-branches, partially with percolating flow

A4: Disconnected side-branches

A5: Erosion pools within the active channel

A6: Backwaters and riparian wetlands at lower levels within the floodplains

A7: Wetlands along hillslope streams entering the floodplains

Terrestrial habitats within the AC on coarse grained sediments

B0: Initial habitats on coarse-grained sediment bars without vegetation or with sparse seedlings, $<0.5$ years old, $<5 \%$ cover

B1: Pioneer habitats on coarse-grained sediment bars with seedlings of annual and perennial herbs (dominant) and woody species $(>1 / 2-1.5$ years old, $1-30 \mathrm{~cm}$ high, $<15 \%$ cover $)$

B2: Shrub on coarse-grained sediment bars with dominant woody species $(>1.5-3$ years old, 50-200 cm high)

Terrestrial habitats within the AC on fine grained sediments

C0: Initial habitats on fine-grained sediment, bars without vegetation or with sparse seedlings, 0.5 years old, $<5 \%$ cover

C1: Pioneer habitats on fine-grained sediment bars with seedlings of annual and perennial herbs and woody species

$(0,5-1.5$ years old, $1-30 \mathrm{~cm}$ high, $<15 \%$ cover $)$

C2: Shrub on fine-grained sediment, bars and islands (annual and perennial herbs and woody species $(>1.5-3$ years, 50-200 cm high)

At elevated islands within the AC and on the floodplains

BC3: Closed shrub on sediment bars and islands with dominating woody species and perennial herbs $(>3-8$ years

old, = $>200 \mathrm{~cm}$ high)

BC4: Woodland with beginning humus accumulation on higher islands and elevated floodplain levels ( $>8-30$ years, till $10 \mathrm{~m}$ tall)

Degradation types

D: Heavily grazed and/or regularily burned Imperata-grasslands with a variety of shrub species, e.g. Tamarix parviflora, Vitex agnus-castus and Platanus orientalis

Table 2 Habitat composition in the Vjosa floodplain (see Table 1; in \% of the AC area) and habitat turnover rates (in \% per year) within the AC

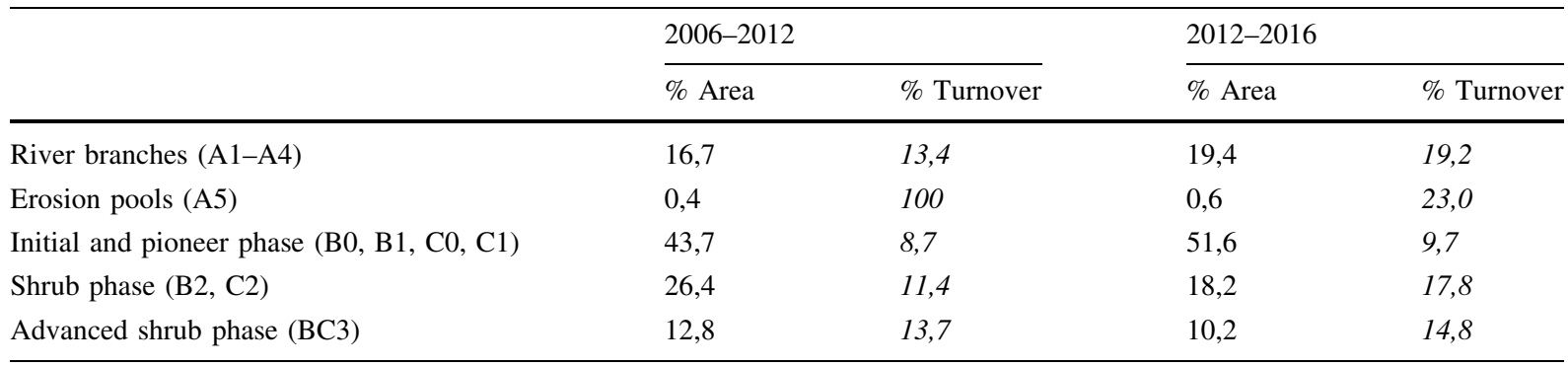

The values refer to the study area delineated in Fig. 2. The average area of the AC and of the active floodplain (AF) are 560 ha each

active channel are specifically short-lived due to erosion and sedimentation, with a life-cycle of less than one year.

Our data highlight two significant features of habitat dynamics (see also Fig. 6a): firstly, the proportion of habitat elements remains constant over time, but-secondly-the continuous shift in the location of the various habitat types indicates a fast turnover and renewal cycle: the whole river-floodplain 
system is in a state of a dynamic hydro-morphological equilibrium. Accordingly, we found that:

(a) Microhabitat availability is continuously shifting with water level fluctuations and small scale sediment transport processes above a flow of $300-350 \mathrm{~m}^{3} \mathrm{~s}^{-1}$.

(b) The average renewal rate of aquatic and riparian habitats in the AC occurs at a time scale of approx. every 5-10 years due to the cumulative effect of regular, annual floods (HQ 1) (see Table 2 and Fig. 5).

(c) Restructuring of the complete floodplain occurs in an order of 50-100 years as a compound result of major flood events.

We suggest that this pattern found for the Vjosa is characteristic for large, undisturbed Balkan gravel bed rivers.

The generalized model of vegetation succession in context with habitat turnover (Fig. 6b) shows that succession on gravel deposits starts with herbs and grasses (Chondrilla juncea, Dittrichia graveolens, Cynodon dactylon, Tragus racemosus-B0), followed by seedlings of Tamarix parviflora, Salix spp. ( $S$. amplexicaulis, S. eleagnos, S. alba) and Populus nigra (B1) which develop into a low shrub (B2). The initial stage of succession on silt and sand (C-series) is dominated by Agrostis stolonifera and Xanthium italicum $(\mathrm{C} 0)$, followed by a pioneer stage with seedlings of Vitex agnus-castus, Platanus orientalis, Populus alba and Alnus glutinosa (C1) which require higher soil moisture for development to a shrubby pioneer stage (C2). Besides these species a wide variety of herbs prevail as pioneers.

At higher levels a shrub phase on mixed gravel and sand develops (BC3, see above) with woody species (Salix spp., Populus nigra, Platanus orientalis, Populus alba, Alnus glutinosa). On larger islands within the $\mathrm{AC}$ and at the elevated floodplain the succession is leading potentially to an early riparian woodland as the final stage of a floodplain turnover cycle (BC4). Platanus and Alnus dominate the tree layer and Rubus sanctus, Brachypodium sylvaticum are main elements of the understorey. Floristic differences to Alpine and Northern Balkan gravel bed rivers are outlined in Appendix A.

All herb species mentioned above as well as the dominant floodplain forest species represent different types of anemochory (wind dispersal). The only exception is Vitex agnus-castus which is barochorous and also able to reproduce vegetatively. Dispersal mode combined with the timing of receding water levels play an important role for germination and vegetation development on newly created sand and gravel bars.

Frequent aggradation of sand supports the spreading of the alien cogongrass Imperata cylindrica. At the elevated floodplain and at higher locations ("islands" within the AC), regular burning and pasturing leads to a dominance of this species with tussocks of Saccharum ravennae and scattered shrubs of Vitex agnuscastus and Platanus orientalis as a final degradation stage (D). Without regular burning or when burning is stopped, the vegetation would develop into a Platanus orientalis-Alnus glutinosa woodland.

In the short-lived stagnant erosion pools (A5) filamentous algae, Chara cf. vulgaris and Nasturtion-communities are found. In former active channels abandoned from the main channel within the floodplain (A6), or in wetlands along hillslope streams entering the floodplain assemblages of Nasturtion, Glycerio-Sparganion and Phragmition alliances can develop, followed by Salix triandra and $S$. alba leading potentially to an Alnus glutinosa-Populus alba forest.

Fluvial dynamics as the basis for the high and specific biodiversity

The widely undisturbed river dynamics in the Vjosa catchment enables the development of the entire spectrum of floodplain ecosystems from unvegetated gravel bars to floodplain forests. They are of outstanding importance and in an excellent conservation status. All riverine habitats typical for the Vjosa are listed in Annex 1 of the European Union Habitats Directive (92/43/EEC, amended document from June 10th, 2013). The riverine habitats $3220,3250,3230,3240$, 92D0, 6210 and $92 \mathrm{C} 0$ are covering $86 \%$ of the total area of the Poçemi-Kalivaçi river corridor. This underpins the importance of the Vjosa river corridor at a European scale (Table 3).

The fish fauna is an important indicator for the ecological integrity of large river systems as a broad spectrum of habitat conditions are required to fulfil the habitat needs of different ecological guilds in the course of their life cycle (Schiemer and Waidbacher 1992). The Balkan rivers are characterized by 
Europe's highest concentration of endemic fish species (Freyhof and Brooks 2011). Shumka et al. (2018a) list 31 fish species inhabiting the Vjosa river system including the critically endangered species Anguilla anguilla (European eel) and endangered species Aphanius ibericus (Spanish toothcarp) and Gobio skadarensis (Skadar gudgeon) according to IUCN criteria. Furthermore, the Vjosa's fish fauna is characterized by several species endemic to the Balkans e.g. Barbus prespensis (Prespa barbel), Luciobarbus albanicus (Albanian barbel), Pachychilon pictum (Albanian roach) and Oxynoemacheilus pindus (Pindus stone loach).

The Vjosa is a large migration corridor for both anadromous and catadromous species as well as other saltwater species entering the system. Meulenbroek (in litt.) documented Anguilla anguilla from $100 \mathrm{~mm}$ up to $510 \mathrm{~mm}$ length up to the boarder to Greece.

Table 3 The characteristics, conservation value and the areal representation of the four main habitats of the Vjosa floodplain in the study site. Given are the habitat type (first column), a short characterization of the habitat type (second column), the corresponding Natura 2000-habitat type (Council Directive 92/43/EEC of 21 May 1992, version 2013, April 25) (third column), the corresponding habitat name in the EUNIS classification 2004/2012 (fourth column), the assessment in
These findings indicate that Mediterranean rivers are significant for the conservation of the European eel stock. The river potentially provides habitat and spawning sites for anadromous sturgeons (Acipenseridae) such as the critically endangered Acipenser sturio and Acipenser naccarii, which are found along the Albanian coast (Freyhof and Brooks 2011). The assessment of the fish fauna (Meulenbroek et al. 2018) showed distinct differences in the distribution of species and their ontogenetic stages within the riverine habitat range (A1-A5) indicating the need for a broad spectrum of habitat conditions in terms of water depth, flow velocities and substrate types, that provides the basis for species and ontogenetic niches of the characteristic assemblages.

Many taxonomic groups of aquatic and terrestrial invertebrates are not, or only sparsely treated in the IUCN Red List, the Bern Convention list or the

European Red List of Ecosystems EU 28+ (Janssen et al. 2016) (fifth column), and an approximation of the area of occurrence along Vjosa river in the study site (column six). Abbreviations: $\mathrm{EN}=$ endangered, $\mathrm{VU}=$ vulnerable, $\mathrm{LC}=$ least concern. The percentage values provided under "areal representation" refer to the morphological floodplain of the Pocemi and Kalivaci area

\begin{tabular}{|c|c|c|c|c|c|}
\hline Habitat type & Characteristics & FFH-Annex I/Natura $2000^{\mathrm{a}}$ & $\begin{array}{l}\text { EUNIS habitat } \\
\text { classific. } 2004 / 2012^{b}\end{array}$ & $\begin{array}{l}\text { EU } \\
\text { red } \\
\text { list }^{c}\end{array}$ & $\begin{array}{l}\text { Areal } \\
\text { representation }\end{array}$ \\
\hline Gravel/sand bars & $\begin{array}{l}\text { Highly dynamic, } \\
\text { regularly } \\
\text { flooded }\end{array}$ & $\begin{array}{l}3220 \text { Alpine rivers and the herbaceous } \\
\text { vegetation along their banks }\end{array}$ & $\begin{array}{l}\mathrm{C} 3.62 \text { Unvegetated } \\
\text { river gravel banks }\end{array}$ & VU & High, $6.8 \%$ \\
\hline Initial vegetation & $\begin{array}{l}\text { Highly dynamic, } \\
\text { regularly } \\
\text { flooded }\end{array}$ & $\begin{array}{l}3250 \text { Constantly flowing } \\
\text { Mediterranean rivers with Glaucium } \\
\text { flavum }\end{array}$ & $\begin{array}{l}\text { C3.553 } \\
\text { Mediterranean } \\
\text { river gravel } \\
\text { habitats }\end{array}$ & VU & High, $20.5 \%$ \\
\hline $\begin{array}{l}\text { Mediterranean } \\
\text { riparian scrub }\end{array}$ & $\begin{array}{l}\text { Fairly dynamic, } \\
\text { annually flooded }\end{array}$ & $\begin{array}{l}\text { 92D0 Southern riparian galleries and } \\
\text { thickets (Nerio-Tamaricetea, } \\
\text { Securinegion tinctoriae) }\end{array}$ & $\begin{array}{l}\text { F9.31 Oleander, } \\
\text { chaste tree and } \\
\text { tamarisk galleries }\end{array}$ & $\mathrm{LC}$ & High, $8.8 \%$ \\
\hline $\begin{array}{l}\text { Mediterranean and } \\
\text { Macaronesian } \\
\text { riparian woodland }\end{array}$ & $\begin{array}{l}\text { Pioneer floodplain } \\
\text { forest, regularly } \\
\text { flooded }\end{array}$ & $\begin{array}{l}\text { 92C0 Platanus orientalis and } \\
\text { Liquidambar orientalis woods } \\
\text { (Platanion orientalis) }\end{array}$ & $\begin{array}{l}\text { G1.3157 East } \\
\text { Adriatic poplar } \\
\text { galleries }\end{array}$ & EN & Low, $1.8 \%$ \\
\hline
\end{tabular}

${ }^{\mathrm{a}}$ European Commission 2013. Interpretation Manual of European Union Habitats based on Council Directive 92/43/EEC of 21 May 1992 on the conservation of natural habitats and of wild fauna and flora], EUR28 Version, April 252013

https://ec.europa.eu/environment/nature/legislation/habitatsdirective/docs/Int_Manual_EU28.pdf

https://eur-lex.europa.eu/legal-content/DE/TXT/PDF/?uri=CELEX:32013L0017\&from=DE

${ }^{\mathrm{b}}$ European Environment Agency (EEA) 219. EUNIS habitat type hierarchical view. Revised version.[Accessed 2019-08-28] https:// eunis.eea.europa.eu/habitats-code-browser.jsp

${ }^{\mathrm{c}}$ Janssen J.A.M. et al. 2016. European Red List of Habitats, 2. Terrestrial and freshwater habitats. Publications Office of the European Union. https://doi.org/10.2779/091,372, Keith et al. 2013 
Albanian Red List of endangered species. To evaluate the conservation status of such taxa we have to refer to their decline in geographic occurrence and population size in Central Europe over the past decades.

Macroinvertebrates are a main component for the biological quality assessment in the European Water Framework Directive (Hering et al. 2010). Our survey, which gives only a snapshot of the existing diversity at the catchment scale, yielded 143 species thus far, of which approx. 50\%-according to "Fauna Europaea" (https://fauna-eu.org) — are new to the fauna of Albania. It includes species endemic to the western Balkans (e.g. Ephemeroptera: Rhithrogena neretvana, Ecdyonurus puma, Ephemerella maculocaudata, and Trichoptera: Rhyacophila diakoftensis, Rhyacophila balcanica, Rhyacophila loxias, Micrasema sericeum, Thremma anomalum, among others), and vital populations of pan-European species like the Plecoptera Marthamea vitripennis and Xanthoperla apicalis, the Ephemeroptera Neoephemera maxima and Prosopistoma pennigerum and the aquatic beetle Potamophilus acuminatus (Coleoptera: Elmidae). These species were formerly widely distributed in large, dynamic rivers across Central and Eastern Europe and are now on their decline (see Graf et al. 2018, Bauernfeind 2018) and are considered to be endangered at a European scale. A detailed list with an evaluation of the conservation status of individual species is provided in Appendix B).

The significance of the intact fluvial dynamics is illustrated here with the example of the ground beetle fauna (Carabidae, see Paill et al. 2018). The species richness in the Vjosa river corridor is enormous considering the limited collection time and the small river section which has been studied so far. 112 species have been documented. This exceeds the species richness of carabids in most other near-natural river systems in Europe (e.g. Plachter 1986). In the Tagliamento in Northern Italy, for example, 185 carabid species have been found based on an investigation over the whole river length from headwaters to the estuary over a period of more than 20 years (Kahlen 2009). From the 112 species (2,327 specimens) collected on the Vjosa, 70 (1566 specimens) were exclusively found within the active channel (AC). The relative abundance of stenotopic riparian species reached values of $93 \%$ to $97 \%$ (in terms of individual numbers) in the regularly flooded levels of the AC, but only $4 \%$ in the higher floodplains. In the
AC the faunistic patterns vary at a small scale between different habitat types especially in the highly dynamic initial and early pioneer stages where $36 \%$ of individuals belonged to species almost exclusively found on gravel substrates (B0-B2) and 57\% exclusively on sand $(\mathrm{C} 0-\mathrm{C} 2)$. In the older succession stage (BC3 and D) the proportion of species found exclusively here is low (1-2\% of all individuals). Also in terms of ecological traits (e.g. flight ability, body size) a clear pattern of habitat preferences is evident: in the continuously changing early pioneer habitats on sand (C0-C2), species with high mobility and re-colonisation capability dominate (e.g. Cicindela monticola albanica or Bembidion quadricolle) making up 40 to $50 \%$ of the abundance. This is linked to the patchy structure, small size and time-restricted availability of moist conditions of the sand bar habitats. The large number of species found and the high percentage of stenotopic floodplain-species which have become very rare throughout Europe (e.g. Bembidion quadricolle, B. scapulare, B. striatum, Stenolophus discophorus, and Poecilus striatopunctatus) underlines the high conservation value of the Vjosa. It represents a genetic pool of international significance (for details see Appendix C).

Other invertebrate species are also well represented. Among orthopterans Saga pedo is listed as a strictly protected species in Appendix II of the Bern Convention. Sphingonotus coerulans, Acrotylus insubricus, Xya pfaendleri and Xya variegata, are listed on the European Red List (see Rabl and Kunz 2018).

Our assessment of the terrestrial vertebrate fauna also confirms the high ecological value of the project area. Of the amphibians and reptilians recorded, the following are listed either in Appendix II of the EU Habitats Directive- strictly protected fauna species (Bufotes viridis, Bombina variegata, Testudo hermanni, Emys orbicularis, Mauremys rivulata, Pseudopus apodus, Podarcis muralis, Podarcis tauricus, Lacerta trilineata, Lacerta viridis, Natrix tesselata) or Appendix III-protected fauna species (Bufo bufo, Rana graeca, Pelophylax kurtmuelleri, Pelophylax shqipericus, Natrix natrix) of the Bern Convention (see Frank et al. 2018; Shumka et al. 2018b). 


\section{Discussion and summary}

The Vjosa and its surrounding habitats are of high conservation value as both the main channel and the riparian landscape comprise a mosaic of habitat types with specific turnover cycles along an undisturbed longitudinal river continuum. A "natural flood regime" (Poff et al. 1997) associated with a "natural sediment regime" (Wohl et al. 2015) generate a high spatio-temporal heterogeneity, a continuous habitat rejuvenation and biotic successions. The wide range of habitat types and ecotones in combination with dynamic water level fluctuations provide the conditions for the specific associations of well adapted rheophilic and riparian species, and high levels of alpha, beta and gamma diversity (Ward et al. 1999). Extensive studies of other large undammed gravelbedded rivers in the temperate zone-e.g. the Tagliamento in Italy (e.g. van der Nat et al. 2002) or the Flathead river in Montana, USA (e.g. Stanford et al. 2005)—revealed a similar critical role of fluvial dynamics for maintaining habitat and biotic biodiversity. In the majority of European countries such natural characteristics of large, dynamic rivers are no longer present (see Fig. 1).

The high abundances of a typical and critically endangered riverine fish community throughout the whole river course highlight the importance of habitat diversity and the undisturbed longitudinal river continuum (Meulenbroek et al. 2018; Schiemer 2000). The aquatic invertebrate communities harbor viable populations of highly threatened species that have largely or completely disappeared from other European rivers. The syntopic occurrence of such potamophilous species underlines the high conservation value of the Vjosa. The key features of rivers still colonised by such characteristic guilds in their different development stages are high fluvial dynamics which provide connectivity within a spatio-temporal habitat mosaic and buffer capacity against physical disturbances. The same holds true for the riparian fauna and vegetation. The high numbers and prevalences of stenotopic floodplain carabids for example, are unparalleled, while densities of rare habitat specialists among the accompanying flora were entirely unexpected.

Moreover, all species found are classified as typical elements of the Natura 2000 habitat types 3220 (alpine fast flowing rivers) and 3230 (alpine rivers, gravel bars with ligneous vegetation). Thus, the high conservation value of the Vjosa is evident. With the impending habitat degradation and fragmentation by dam constructions we expect a massive decline in abundances and the local extinction of several species in the area. Lessons learned from other European rivers underpin the negative ecological effects of river-damming (Poff et al. 2007). Dams homogenize the flow dynamics of rivers and reduce their geomorphic complexity (Graf 2006).

Decision-makers and stakeholders should be aware of the profound consequences and major environmental threats of dam construction on intact rivers (Tockner et al. 2008). Today, the ecological and morphological status of highly modified rivers in many European countries is being improved by costly restoration measures. Besides environmental issues, negative socio-economic side-effects should be considered when deciding on the construction of hydropower plants (see Buijse et al. 2005). In the case of the Vjosa, a major challenge is the high sediment load of the river that (i) will reduce efficiency of dam operation while (ii) increasing river bed incision downstream of the dam and coastal erosion. These effects will affect the quality-of-life and economic prospect of the local population (Hauer et al. 2019).

Finally, there are operational and legal concerns regarding the planned hydropower dams: during the past 20 years, water body management is developing standardized operational procedures, which should be adhered to. In EU countries, for example, river management must follow the European Water Framework Directive (2000/60/EC), Natura 2000 Directive, EU Birds and Habitats Directives (92/43/EEC) and EU Flood Risk Directive (2007/60/EU). These regulations stipulate that projects have to evaluate short-, medium-, and long-term impacts on nature and affected residents and must consider alternative lowimpact concepts. Important water policy instruments such as the Water Framework Directive of the EU request a comprehensive catchment-wide planning process with clearly defined procedural steps. We call for a platform to be established at the science-policy interface, where scientists interact with policymakers, authorities and other stakeholders. Such a platform should be used to explore scenarios for the sustainable development of the Vjosa river corridor, acknowledging the interdependence of the integrity of riverine ecosystems with economic, social and cultural aspects 
of human well-being. The present multidisciplinary baseline studies on the ecological and morphological status of the Vjosa form a prerequisite for any assessments of the ecological effects caused by dam construction. Such studies should be adopted as a standard for river management in the Balkan area, where widespread data deficiency currently prevents the elaboration of appropriate environmental impact assessments.

Finally, in light of the extraordinary biodiversity and uniqueness of the Vjosa river-floodplain ecosystem, we call for the Vjosa to be protected by evaluating different options including the establishment of a protected area (e.g. national park) to ensure that the outstanding conservation value is being secured. The Bern Convention of the European Council has already opened a case file at the 38th Standing Committee meeting in 2018 on the Vjosa. The Convention recommended to the Albanian Government to suspend all dam projects on the Vjosa river and prepare an integrated River Basin Management plan, as well as a strategic environmental impact assessment including social aspects in collaboration with Greece.

Acknowledgements Open access funding provided by University of Vienna. We would like to thank our colleagues who took part in the "Science week" in April 2017, in particular Klodian Skrame for his help in the bathymetric assessment of the landscape relief. The field work in Albania received organizational and financial support from the NGO's Euronatur, RiverWatch and Eco-Albania. The article benefited greatly from comments of three anonymous reviewers.

Open Access This article is licensed under a Creative Commons Attribution 4.0 International License, which permits use, sharing, adaptation, distribution and reproduction in any medium or format, as long as you give appropriate credit to the original author(s) and the source, provide a link to the Creative Commons licence, and indicate if changes were made. The images or other third party material in this article are included in the article's Creative Commons licence, unless indicated otherwise in a credit line to the material. If material is not included in the article's Creative Commons licence and your intended use is not permitted by statutory regulation or exceeds the permitted use, you will need to obtain permission directly from the copyright holder. To view a copy of this licence, visit http://creativecommons.org/licenses/by/4.0/.

\section{References}

Bauernfeind E (2018) Mayflies (Ephemeroptera) of the River Vjosa. Albania Acta ZooBot Austria 155(1):155-162
Buijse AD, Klijn F, Leuven RSEW, Middelkoop H, Schiemer F, Thorp JH, Wolfert HP (2005) Rehabilitation of large rivers: references, achievements and integration into river management. Arch. Hydrobiol. Suppl. 115(Large Rivers 15):715-738

Copp GH, Peňáz M (1988) Ecology of fish spawning and nursery zones in the flood plain, using a new sampling approach. Hydrobiologia 169(2):209-224

Deslodges JR, Church MA (1989) Wandering gravel bed rivers. Can Geogr 33:360-364

Drescher A (2018) The Vjosa-the floodplains of an outstanding gravel bed river in southern Albania. Acta ZooBot Austria 155:85-105

Eco-Masterplan for Balkan rivers (2018) "Save the Blue Heart of Europe" campaign

Egger G, Randl M, Drescher A (2019) Scientific programme: baseline survey for an Environmental Impact Assessment of the River Vjosa in Albania: Vegetation and Riparian Habitats. Report to Riverwatch

Fauna Europaea: https://fauna-eu.org/cdm_dataportal, assessed on 17.8.2019

Frank T, Sacdanaku E, Duda M, Bego F (2018) Amphibian and reptile fauna of the Vjosa river, Albania. Acta ZooBot Austria 155:323-336

Freyhof J, Brooks E (2011) European red list of freshwater fishes. Publications Office of the European Union, $61 \mathrm{pp}$. DOI: $10.2779 / 85903$.

Graf WL (2006) Downstream hydrologic and geomorphic effects of large dams on American rivers. Geomorphology 79:336-360

Graf W, Grabowski M, Hess M, Heckes U, Rabitsch W, Vitecek S (2018) Aquatic invertebrate fauna of the Vjosa in Albania. Acta ZooBot Austria 155:135-153

Google Earth (2018) Satellite Images Worldwide. Digital Globe, 2018, http:// www. earth.google.com.

Griffith HI, Krystufek B, Reed JM (2004) Balkan biodiversity: pattern and process in the European hotspot. Springer, Netherlands, $358 \mathrm{p}$

Hauer C, Aigner H, Fuhrmann M, Holzapfel P, Rindler R, Pessenlehner S, Pucher D, Skrame K, Liedermann M (2019) Measuring of sediment transport and morphodynamics at the Vjosa River/Albania. Report to Riverwatch

Hering D, Borja A, Carstensen J, Carvalho L, Elliot M, Feld CK, Heiskanen A-S, Johnson RK, Moe J, Pont D, Solheim AL, Van De Bund W (2010) The european water framework directive at the age of 10: a critical review of the achievements with recommendations for the future. Sci Total Environ 408:4007-4029

Hill MO (1979) Twinspan-a Fortran program for arranging multivariate data in an ordered two-way table by classification of individuals and attributes. Cornell Univ, Ithaka, New York

Janssen JAM, Rodwell JS, Criado MG, Gubbay S, Haynes T, Nieto A, Sanders N, Lan-ducci F, Loidi J, Ssysmak A, Tahvanainen T (2016) European red list of habitats. Part 2. Terrestrial and freshwater habitats. https://doi.org/10. 2779/091372

Kahlen M (2009) Die Käfer der Ufer und Auen des Tagliamento (II. Beitrag: Ergänzende eigene Sammelergebnisse, Fremddaten, Literatur). Gortania Botanica, Zoologica $31: 65-136$ 
Keith DA, Rodríguez JP, Rodríguez-Clark KM, Nicholson E, Aapala K, Alonso A, Asmussen M, Bachman S, Basset A, Barrow EG, Benson JS (2013) Scientific foundations for an IUCN red list of ecosystems. PLoS ONE 8:1-25

Meulenbroek P, Shumka S, Schiemer F (2018) First reconnaissance of habitat partitioning and fish diversity in the alluvial zone of the river Vjosa, Albania. Acta ZooBot Austria 155:177-186

Nanson GC, Knighton AD (1996) Anabranching rivers: their cause, character and classification. Earth Surf Proc Land 21:217-239

Paill W, Gunczy J, Hristovski S (2018) The Vjosa-floodplains in Albania as natural habitat for ground beetles: a hotspot of rare and stenotopic species (Coleoptera: Carabidae). Acta ZooBot Austria 155:269-306

Plachter H (1986) Composition of the carabid beetle fauna of natural riverbanks and of man-made secondary habitats. In: Den Broer PJ, Thiele H-U, Weber F (eds) Carabid beetles, their adaptations and dynamics. Gustav Fischer, pp 509-535

Poff NL, Allan JD, Bain MB, Karr JR, Prestegaard KL, Richter BD, Sparks RE, Stromberg JC (1997) The natural flow regime. Bioscience 47:769-784

Poff NL, Olden JD, Merritt DM, Pepin DM (2007) Homogenization of regional river dynamics by dams and global biodiversity implications. PNAS 104:5732-5737

Rabl D, Kunz G (2018) First insight into the Orthoptera fauna of the Vjosa river floodplain at Pocem (South Albania). Acta ZooBot Austria 155:257-267

Schiemer F (2000) Fish as indicators for the assessment of the ecological integrity of large rivers. Hydrobiologia 422:271-278

Schiemer F, Beqiraj S, Graf W, Miho A (eds) (2018a) The Vjosa in Albania-a riverine ecosystem of European significance. Acta ZooBot Austria 155
Schiemer F, Drescher A, Hauer C, Schwarz U (2018b) The Vjosa river corridor: a riverine ecosystem of European significance. Acta ZooBot Austria 155:1-40

Schiemer F, Waidbacher H (1992) Strategies for conservation of a Danubian Fish Fauna. In: Boon PJ, Calow P, Petts GJ (eds) River conservation and management. Wiley, pp 363-382

Shumka S, Meulenbroek P, Schiemer F, Sanda R (2018a) Fishes of River Vjosa-an annotated checklist. Acta ZooBot Austria 155:163-176

Shumka S, Bego F, Beqiraj S, Paparisto A, Kashta L, Miho A, Nika O, Marka J, Shuka L (2018b) The Vjosa catchmenta natural heritage. Acta ZooBot Austria 155:349-375

Stanford JA, Lorang MS, Hauer FR (2005) The shifting habitat mosaic of river ecosystems. Verh. Internat Verein Limnol 29:123-136

Tockner K, Bunn SE, Gordon C, Naiman RC, Quinn GP, Stanford JA (2008) Flood plains: critically threatened ecosystems. In: NVC Polunin (ed) Aquatic ecosystems: trends and global prospects, Cambridge University Press, pp 45-61

Van der Nat D, Schmidt AP, Tockner K, Edwards PJ, Ward JV (2002) Inundation dynamics in braided floodplains: Tagliamento River, Northeast Italy. Ecosystems 5:636-647

Ward JV, Tockner K, Schiemer F (1999) Biodiversity of floodplain river ecosystems: ecotones and connectivity. Regul Rivers Res Manag 15:125-139

Wohl E, Bledsoe BP, Jacobsen RB, Poff NL, Rathburn SL, Walters DM, Wilcox AC (2015) The natural sediment regime in rivers: broadening the foundation for ecosystem management. Bioscience 65:358-371

Publisher's Note Springer Nature remains neutral with regard to jurisdictional claims in published maps and institutional affiliations. 